\title{
MYOMETRIAL ACTIVITY DURING PREGNANCY AND PARTURITION IN THE PIG
}

\author{
M.A.M. TAVERNE \\ Clinic for Veterinary Obstetrics, A.I. and Reproduction, State University of \\ Utrecht, The Netherlands
}

In contrast to the quite substantial number of publications on the endocrine control of parturition in the pig (First and Bosc, 1979; Ellendorff $e$ t al., 1979a; First, Chapter 16), very little information is available on the actual activity of one of the most important target tissues, i.e. the myometrium. Including studies on the non-pregnant uterus, only about twenty papers have appeared on this topic during the last twenty years. Many therapeutic measures have been undertaken to reduce the rate of stillbirths in the pig (Sprecher et al., 1974; Dziuk, 1979) without a documented knowledge of their ultimate effects on uterine contractions during the parturition process. One can hardly believe in a species of such economic importance and from which tissue samples are easily obtainable, that even some of the very basic questions on the morphology of the myometrium still remain to be answered. (a) Is the architecture of the porcine myometrium, where muscle fibres have been reported to traverse from the outer to the inner layer only incidently (Nagler, 1956), really different from other polytocous species, like the rat, where the two layers were found to be built up by the same bundles of muscle cells (Ludwig, 1952)? (b) What is the relative distribution of cholinergic and adrenergic nerve fibres in the myometrium during pregnancy and parturition? (c) Are changes in the density of the innervation, if they exist, under hormonal control, as reported for the myometrium of the non-pregnant pig (Colenbrander, 1974)?

This chapter will summarize some of the more recent data on other aspects of uterine physiology such as (a) the temporary changes in myometrial activity around parturition, (b) the mechanical aspects of the delivery process, and (c) the in vivo and/or in vitro measurement of the effects of progesterone, oestrogens, oxytocin, prostaglandins and catecholamines on the myometrium of the pig.

\section{Evolution of uterine contractions}

Spontaneous changes in uterine activity during late pregnancy and parturition have been investigated by in vivo recordings of intrauterine pressure changes (Zerobin, 1968; Zerobin and Spörri, 1972; Ngiam, 1974; 1977) and by uterine electromyography (Zerobin, 1968; Zerobin and Spörri, 1972; 
Taverne, Naaktgeboren and van der Weyden, 1979; Taverne et al., 1979). Although the pressure recordings made during the last weeks of gestation have revealed the existence of only feeble, local contractions that occur asynchronously with electrical activity (Zerobin and Spörri, 1972), prolonged EMG recording sessions performed during the last three weeks of pregnancy in the miniature pig have demonstrated the existence of a definite pattern of myometrial electrical activity (Taverne et al., 1979). Episodes of EMG activity of several minutes' duration occur with low frequency (0.5-3.5/hour) in uterine segments that contain a piglet while empty parts of the uterus are relatively inactive.

A similar pattern of myometrial electrical activity has been found in the sheep (Naaktgeboren et al., 1975; Prud'homme and Bosc, 1977), the cow (Taverne, van der Weyden and Fontijne, 1979) and the goat (Taverne and Scheerboom, unpublished data). Implantation of electrodes before a successful mating in the ewe allows EMG recordings to be performed during the entire course of pregnancy (van der Weyden et al., 1981a). Episodes of electrical activity were first detected as early as the 5th week of gestation in the sheep and during the last trimester concurrent recordings of real-time ultrasound images of the ovine conceptus and of EMG activity showed that during these episodes of electrical activity the conceptus is passively displaced within the abdominal cavity of the ewe (Scheerboom and Taverne, 1981). The physiological implications of EMG activity during late pregnancy in the pig remain to be investigated. The observation that this activity sometimes appears in consecutive parts of a pregnant uterine horn (Figure 20.1) indicates that it can be initiated at one foetal compartment and that either a muscular or neural pathway exists for its propagation. However, in most instances no clear propagation can be detected during pregnancy and EMG activity appears more or less synchronously at different foetal locations.

The few studies that have been performed so far indicate that the typical pregnancy pattern of myometrial activity changes only 4-9 hours before expulsion of the first piglet. At this time local contractions have disappeared and bi- or triphasic increases of intrauterine pressure, lasting for 1-3 minutes, occur at regular intervals synchronized with episodes of EMG activity. Empty parts of the uterine horns also contract and the propagation of contractions along the horn in both a tubocervical and cervicotubal direction is frequently observed at this stage of the parturition process.

Further evolution of myometrial activity (i.e. an increase in the frequency and amplitude of the contractions and the gradual appearance of straining efforts of the dam) takes place during the last few hours before the birth of the first piglet but the few data that are available are difficult to compare in a quantitative way because of the differences in the experimental protocols and in the techniques used. In addition, large differences in the characteristics of the uterine contractions between individual sows have been reported (Zerobin, 1968; Figure 20.2). The mean frequency of uterine contractions is maximal during the delivery of the piglets and placentae (Taverne et al., 1979); however, during this stage of parturition, contraction frequency, duration and amplitude may vary considerably from one hour to another (Zerobin, 1968; Ngiam, 1974).

The combination of individual foetal marking with uterine electromyography in the minipig showed that both the duration and the direction of 


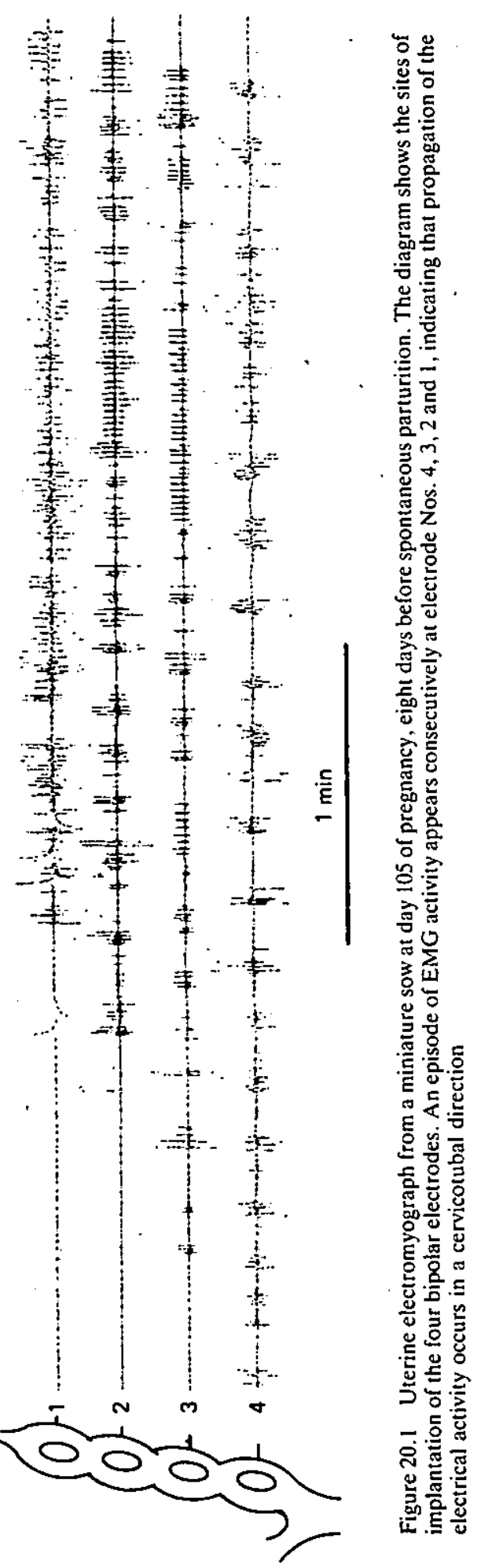




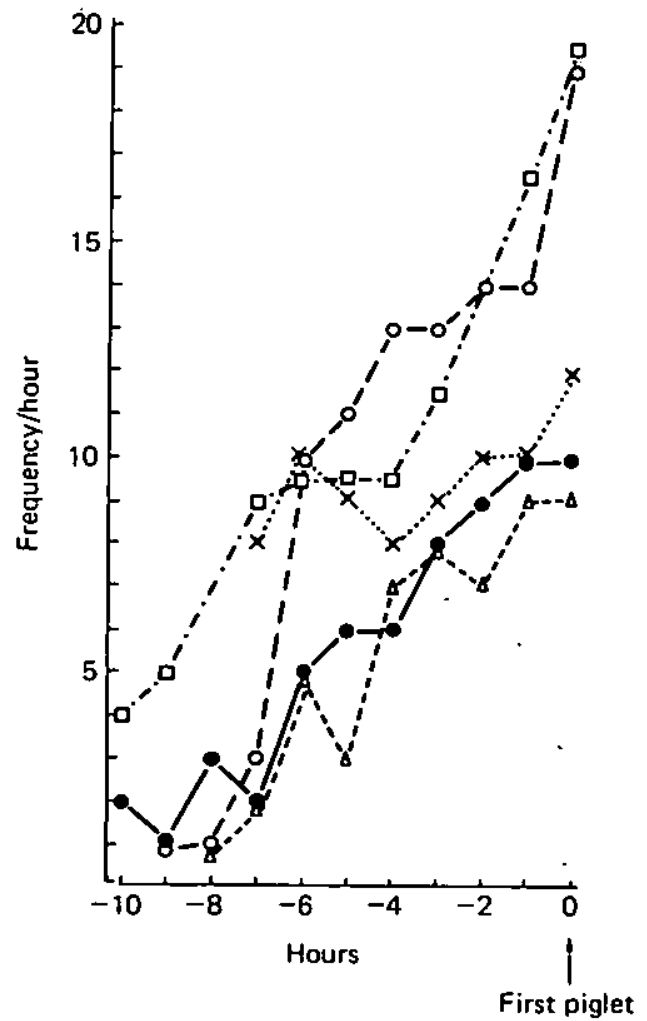

Figure 20.2 The increase in the frequency (per hour) of episodes of myometrial electrical activity in five miniature sows during the 10 -hour period preceding the spontaneous delivery of the first piglet. (In each sow the surface electrode had been implanted in the middle of a foetal compartment, at least seven days before.)

the propagation of uterine contractions change upon emptying of a uterine horn (Taverne, Naaktgeboren and van der Weyden, 1979). Without knowledge of the latter, intrauterine pressure measurements should be interpreted with caution because one cannot be sure that the tip of the catheter is enclosed between a piglet and the uterine wall or that it just remains in an empty portion of the uterine lumen. For this same reason actual values for the pressures that have been measured are only useful when the physical conditions around the tip of the catheter or the balloon remain more or less stable throughout the measurements. The only place where this probably occurs seems to be close to the utero-isthmic junction. These methodological implications should be kept in mind when in vivo studies are performed in the future.

\section{Mechanical aspects of delivery and uterine contractions}

The birth canal along which each piglet must pass consists of that part of the uterus where the piglet is situated, the empty parts of the horn, the 
uterine body, the cervix, the vagina and the vulva. The caudal part of the cervix and the vagina are situated in the bony part of the birth canal that is formed by the more or less rectangular pelvic inlet, the pelvic cavity and the pelvic outlet. It is not known if the cervix and vagina actively contribute to the delivery process.

Transport of foetuses through the uterus is effected by the myometrial contractions. How this transport is achieved has not been investigated in detail in the sow. The importance of research into the nature of an unimpaired and quick transport of piglets through the uterine horns is emphasized by at least three observations:

(a) Two-thirds of all piglets that die during or shortly after delivery are expelled during the final third of the delivery process (Randall, 1972) and a majority of these piglets are born with broken umbilical cords;

(b) Nearly all the piglets which have occupied the most tubal parts of an otherwise empty uterine horn and consequently have had to traverse a long segment of previously unoccupied, undilated uterine tissue before reaching the uterine body, are stillborn (Bevier and Dziuk, 1976);

(c) Surgical inversion of the uterine horn in the sow seriously impairs the normal expulsion of piglets from that horn. (Bosc et al., 1976), thus once again raising the question about the existence of special morphological structures for peristalsis in the uterus.

Multiple implantation of intrauterine catheters (Zerobin, 1968) or surface electrodes (Taverne et al., 1979) have demonstrated the existence of a synchronization of myometrial contractions at all segments of a uterine horn during delivery. Contractions were found to be initiated preferentially at the two ends of the uterine horn and subsequently propagated in either a tubocervical or cervicotubal direction. Even 'echo-propagation' has been documented (Taverne $e t$ al., 1979), i.e. a tubocervically-directed contraction, once it reaches the end of the horn, rebounds in the opposite direction. A combination of foetal marking with uterine electromyography has shown that cervicotubally-directed contractions normally occur during the parturition process until the moment that the horn is empty. The presence of piglets close to the cervix obviously plays a role in the initiation of these cervicotubally-directed contractions during labour. However, the exact function of this type of contraction remains to be elucidated, perhaps by direct observation of the exposed uterus, as has been performed in the parturient rabbit (Carter, Naaktgeboren and van Zon- van Wagtendonk, 1971; Naaktgeboren and Carter, 1971). Nevertheless from the present data two possible functions for these cervicotubal contractions can be postulated:

(1) When contractions start at the caudal part of the uterus they cause an extra shortening of the distance to be traversed by the piglets that are still left within the horn and this additional shortening is superimposed on the retraction of those parts of the uterine horn that have already been emptied (Taverne, 1979).

(2) Cervicotubally-directed contractions retain those pigiets in the horn that are not yet due to be expelled. The uterine horn is transformed 
into a slippery tube by the rupture of the chorionic ends of the individual placentae and this allows piglets to move freely through the chorionic membranes of their neighbours (Perry, 1954; Ashdown and Marrable, 1970). To prevent accumulation of piglets at the caudal part of the horn, transport in the direction of the oviduct would keep the piglets more or less in place and would prevent premature rupture of umbilical cords.

Nothing is known about a possible mutual relationship between contractions in the two horns. Although expulsion of piglets from the two horns takes place by chance (Dziuk and Harmon, 1969; Taverne et al., 1977), complete independence of the two sites seems very unlikely because muscle fibres from both horns fuse at the common uterine body (Leibrecht, 1953; Nagler, 1956). In this respect it would be interesting to make a comparison with the dog in which expulsion of puppies takes place alternately from the two horns in the majority of cases (van der Weyden $e t$ al., 1981b).

\section{Effects of hormones and drugs on the myometrium}

\section{PROGESTERONE AND OESTROGENS}

A relationship between the morphology of the ovaries and the motility of the uterus (in vitro observation) of the sow was reported many years ago (Keye, 1923; King, 1927). In vivo recordings of myometrial activity in the sow have been performed during different stages of the oestrous cycle (as judged by teasing behaviour) in either anaesthetized (Zerobin and Spörri, 1972) or conscious sows (Döcke and Worch, 1963; Bower, 1974). From these studies and from experiments using ovariectomized sows treated with progesterone and/or oestradiol (Zerobin, 1968), one may conclude that changes in steroid hormone production by the ovaries of the cycling sow are responsible for the changes in spontaneous activity of the myometrium. However, concurrent investigations of both uterine contractility and plasma or tissue levels of progesterone and oestradiol have not been published so far for the non-pregnant pig.

The observation in the late pregnant minipig that the onset of the parturient pattern of myometrial contractions is preceded by a significant decrease of the plasma progesterone concentration and a significant increase of the oestrone and oestradiol-17 $\beta$ concentrations (Taverne et al., 1979), raises the question of how essential these steroid changes are for the stimulation of the myometrium.

There are few direct observations to indicate that progesterone suppresses myometrial activity in the pig. Contractions are either of low amplitude or even completely absent during the greater part of the luteal phase of the cycle (Zerobin and Spörri, 1972; Bower, 1974) and in ovariectomized sows treated with progesterone (Zerobin, 1968). However, simultaneous injections of progesterone and very high doses of oestradiol can initiate powerful contractions comparable to those registered during the first and third day of oestrus (Zerobin, 1968). An experiment with one late 
pregnant sow provided with open intraluminal uterine catheters for the recording of myometrial contractions revealed that after six days of treatment with a progestin (CAP), typical uterine pressure waves were absent during parturition. The amplitude of the remaining atypical uterine pressure waves was reduced by about $50 \%$ but their duration was increased and eleven piglets (two of which were dead) had to be delivered manually from the vagina (Jöchle et al., 1974). When a single injection of the prostaglandin $F_{2 \alpha}$ analogue cloprostenol was given to a pregnant sow (provided with uterine surface electrodes) on day 110 of pregnancy, stimulation of the myometrium was not observed immediately after injection. Only 23 hours after injection of the prostaglandin, when peripheral plasma progesterone concentrations had reached values below $5 \mathrm{ng} / \mathrm{ml}$, did the onset of the parturient pattern of myometrial activity take place (Taverne, 1979). This would be in agreement with the data of Ellicott and Dziuk (1973) which suggest that a concentration of about $4 \mathrm{ng} / \mathrm{ml}$ of progesterone in the peripheral plasma appears to be minimal for maintenance of pregnancy in the pig.

Despite the overwhelming evidence that progesterone withdrawal is an essential step in the processes that lead to the normal delivery of piglets (see review by First and Bosc, 1979; First, Chapter 16), the following observations tend to indicate that the activation of the myometrium and complete expulsion of the litter can take place even when the animal is still being treated with progesterone or a progestin, or when peripheral plasma levels of progesterone are still elevated:

(a) In pigs in which surface electrodes were surgically implanted on the uterus during late pregnancy, regular and frequent episodes of EMG activity were recorded during the first week after surgery despite the presence of high circulating progesterone levels in the blood (Taverne, unpublished data);

(b) A single subcutaneous injection of $100 \mathrm{mg}$ progesterone in oil on day 105 of pregnancy in a sow provided with uterine electrodes raised the peripheral plasma progesterone concentration for many days and although an injection of the prostaglandin $F_{2 \alpha}$ analogue, cloprostenol, caused a significant decrease in the plasma progesterone concentrations in this animal, a progesterone level of $14.0 \mathrm{ng} / \mathrm{ml}$ was measured during the spontaneous delivery of three living piglets 30 hours after the injection of cloprostenol (EMG activity in this animal is shown in Figure 20.3);

(c) In some animals continuously treated with progesterone, the delivery of piglets was not prevented (Minar and Schilling, 1970; Ellicott and Dziuk, 1973);

(d) In a recent study it was found that after subcutaneous injections of progesterone for six days, even though delivery was delayed, expulsion of living piglets still occurred while plasma progesterone levels were very high (Taverne et al., 1982);

(e) Current experiments in our laboratory on the EMG activity in the cycling pig indicate that regular bursts of electrical activity occur during the very early stages of luteolysis, when plasma progesterone levels are still elevated (Figure 20.4). 

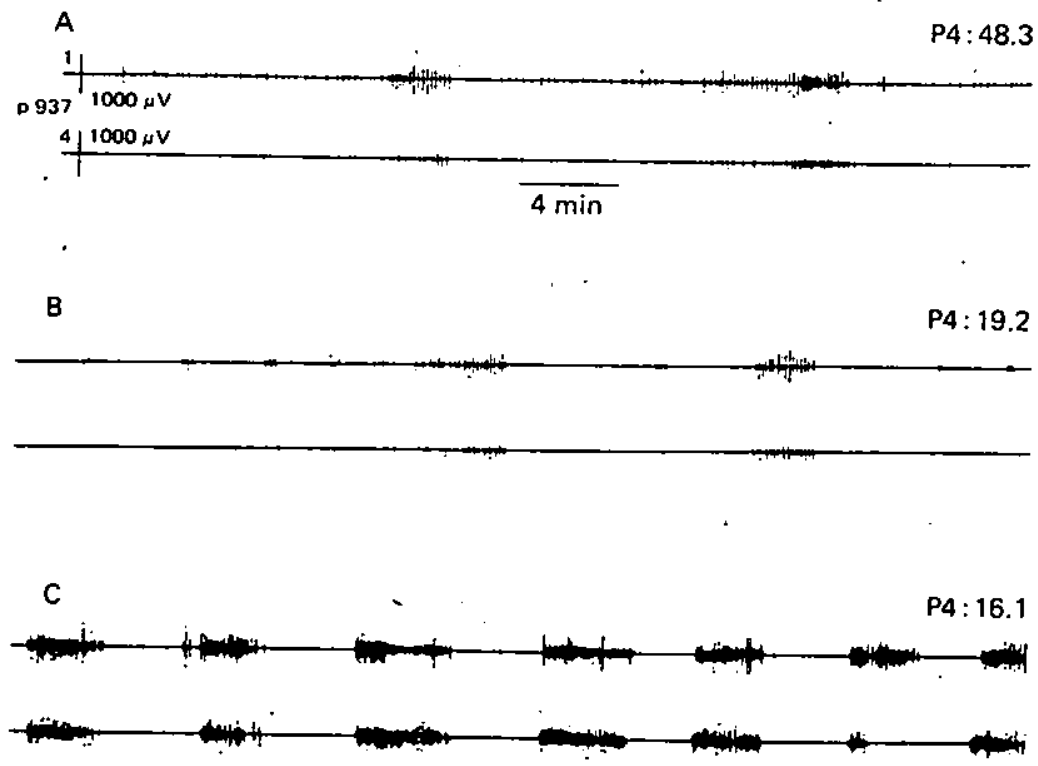

D

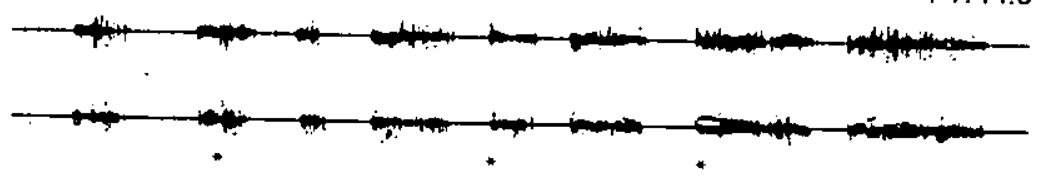

Figure 20.3 Uterine EMGs recorded from two different sites of a horn in a pregnant sow that was injected subcutaneously with $100 \mathrm{mg}$ progesterone (in oil) on day 105 of gestation and in which parturition was induced by a single intramuscular injection of a prostaglandin $\mathrm{F}_{2 \mathrm{a}}$ analogue (ICI 80996, Cloprostenol) on day 110 of gestation. A: day 109 of gestation, one day before prostaglandin injection; B: 14 hours after prostaglandin injection; C: 25 hours after prostaglandin injection; D: during spontaneous delivery of three living piglets $(*) 30$ hours after injection of the prostaglandin analogue. The peripheral plasma progesterone levels indicated $\left(\mathrm{P}_{4}: \mathrm{ng} / \mathrm{ml}\right)$ were estimated according to the method of Dieleman and Schoenmakers (1979)

P4: 15.9
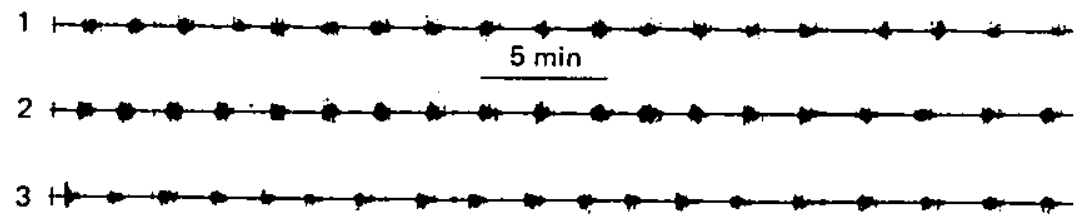

Figure 20.4 Regular bursts of EMG activity recorded from three different sites of a uterine horn in a miniature sow during late dioestrus, six days before the onset of the next oestrus. Peripheral plasma progesterone levels measured $30.9 \mathrm{ng} / \mathrm{ml}$ on the day before, $15.9 \mathrm{ng} / \mathrm{ml}$ during, and $2.6 \mathrm{ng} / \mathrm{ml} 16$ hours after this recording 
MP II

+42 hours

$+1000 \mu v$

+48 hours $+500 \mu \mathrm{V}$

$2 \min$

+54 hours $+1000 \mu \mathrm{V}$

B

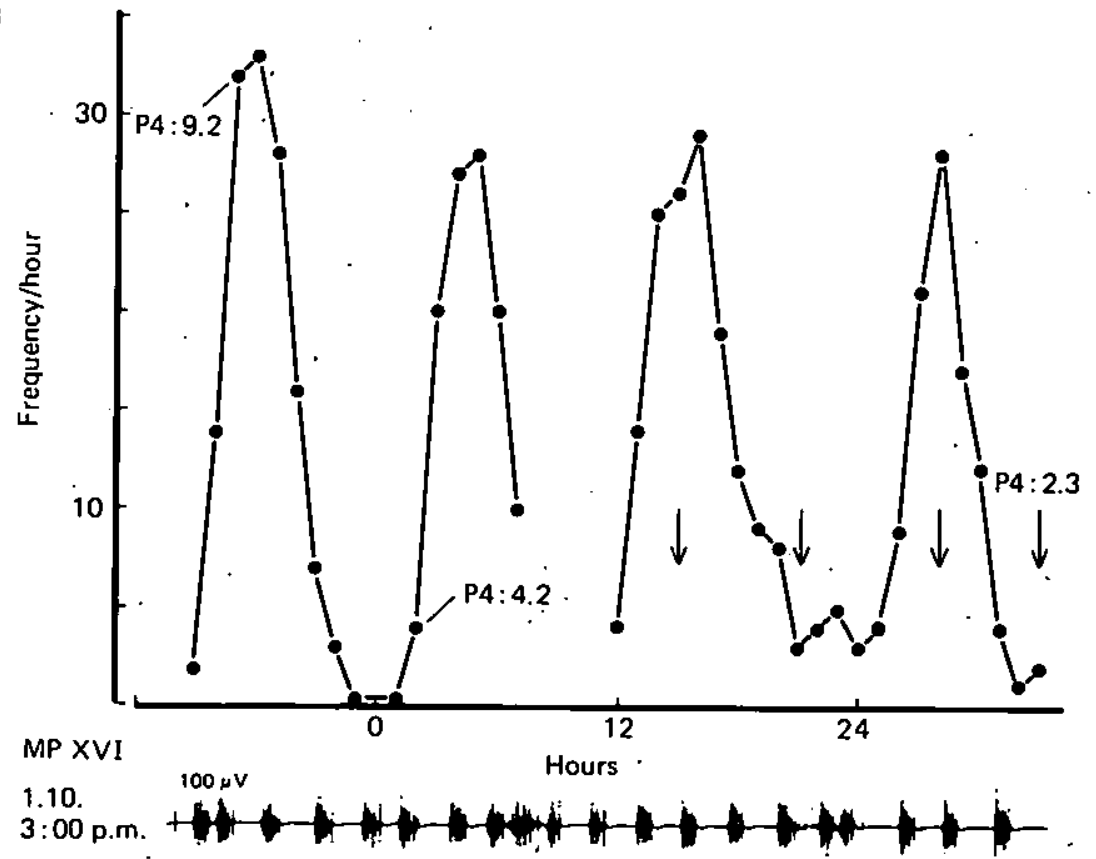

1.10 .

$200 \mu \mathrm{V}$

9: 15 p.m.

2,10 .

4: 25 a.m.

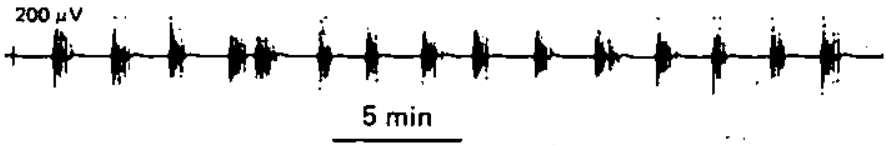

2.10 .

$8: 30$ a.m.

Figure 20.5 A. EMG recorded from one site of a uterine horn in an ovariectomized miniature sow 42,48 and 54 hours after the intramuscular injection of $100 \mu \mathrm{g}$ oestradiol-17ß; (from the 8 th to the 3rd day before the administration of oestradiol, the sow was injected daily with $12.5 \mathrm{mg}$ progesterone). B. The frequency (per hour) of bursts of electrical activity recorded from one site of a uterine horn in a miniature sow during two days of pro-oestrus. Peripheral plasma progesterone levels were determined three times during continuous recording of EMG activity. Four segments of the electromyograph (at times indicated by the arrows in the graph) are shown at the bottom 
Thus there is some doubt about the significance of plasma progesterone levels in relation to the action of progesterone on the myometrium. A similar conclusion was made by Csapo, Eskola and Ruttner (1980) after the treatment of rats with progesterone shortly before the expected time of delivery.

The role of oestrogens for the stimulation of the myometrium at parturition is even less clear. Infusion of oestradiol did not change gestation length in two late pregnant sows (Flint, Ricketts and Craig, 1979). Expulsion of the conceptuses in sows with prolonged pregnancies, in which all the piglets were mummified, has been reported after a single injection of prostaglandins (Wrathall, 1980), even when oestrogen levels can be expected to be very low.

In vitro, the motility of uterine strips obtained from sows during parturition is inhibited when oestradiol is added to the organ bath (Dias e Silva, 1979). However, in vivo, after pretreating ovariectomized nonpregnant sows with progesterone, a single injection of oestradiol-17 $\beta$ induces a cyclic pattern of myometrial electrical activity in which hours with regular and well propagated bursts of electrical activity alternate with hours of almost complete rest (Figure 20.5). This pattern lasts for at least two days after the injection of oestradiol and it is interesting that a similar pattern of EMG activity has been recorded during luteolysis and the greater part of the follicular phase of the oestrous cycle (Figure 20.5). Elevated plasma levels of prostaglandins have been reported during this stage of the cycle (Moeljono et al., 1977; Shille et al., 1979), so one might speculate that prostaglandins are involved in the effects of oestrogens on the myometrium of the pig. This is supported by recent data on the effects of oestrogens on the non-pregnant uterus in sheep that were treated with prostaglandin synthesis inhibitors (Lye, 1980; Prud'homme, 1980).

\section{OXYTOCIN AND PROSTAGLANDINS}

Despite the warning of Zerobin (1968) that an injection of only $10 \mathrm{iu}$ of oxytocin is sufficient to restore contractions in sows with uterine inertia during delivery, oxytocin is probably still one of the hormones that is too frequently misused in farrowing barns.

Even in a recent report on the improvement of synchronization of farrowing after prostaglandin injection, a dose of 50 iu of oxytocin was given several hours before the first piglet was born (Welk and First, 1979). Although oxytocin treatment in this latter study did not cause an additional increase in the incidence of stillbirths, application of drugs to the sow during the periparturient period should be avoided as much as possible when their effects on both the myometrium and uterine vasculature are not known. The pig foetus is very susceptible to intrauterine asphyxia (Randall, 1979) and a prolonged period of intrauterine hypoxia caused by uterine hypertension might deplete the glycogen stores of the piglets that would otherwise help them to survive when they are due to be expelled.

The myometrium of the pregnant pig does not react with frequent and well propagated contractions upon a single injection (intramuscular or intravenous) of even high doses of oxytocin. After application of the drug, 


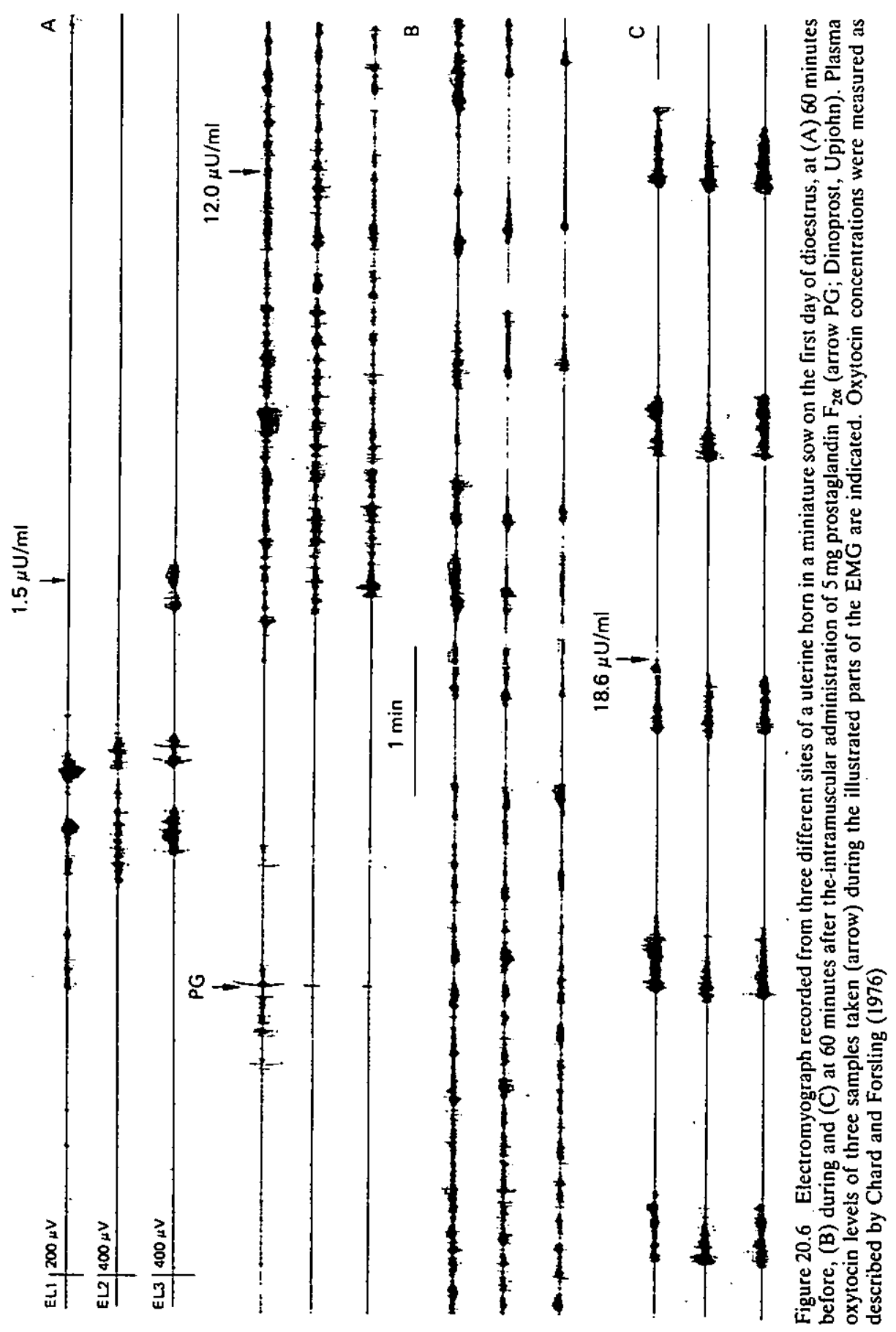


a prolonged slight increase of intrauterine pressure (Zerobin, 1968) and a prolonged episode of EMG activity (Ellendorff et al., 1979b) have been recorded but these subside after several minutes and no further stimulation is seen despite the presence of still elevated peripheral oxytocin levels (Ellendorff et al., 1979b). It would be interesting to know the myometrial response to a more prolonged infusion of oxytocin or to a long acting oxytocin analogue (Cort, Einarsson and Viring, 1979) during late pregnancy, since the presence of oxytocin receptors has been demonstrated in a pregnant pig, about one week before delivery (Soloff and Swartz, 1974). An increase in the density of these binding sites probably occurs shortly before delivery, as judged by the increase of myometrial sensitivity to exogenous oxytocin (Zerobin, 1968) and the elevated levels of oestrogens at this time may be responsible for this (Soloff, 1975).

Evolution of myometrial activity during parturition takes place concurrently with an elevation of the peripheral plasma oxytocin concentration (Taverne et al., 1979; Forsling et al., 1979, Forsling, Macdonald and Ellendorff, 1979). The relative significance of oxytocin stimulation is hard to judge during this stage because prostaglandin $F_{2 \alpha}$ concentrations, as judged by measurements of the 15-keto metabolite, are elevated as well on the day of parturition (Silver et al., 1979; First and Bosc, 1979; Martin, 1980 ). Prostaglandin $F_{2 \alpha}$ can both stimulate the myometrium and cause an oxytocin release in the pig (Ellendorff et al., 1979b; Figure 20.6). In addition in vitro studies with uterine strips taken from sows during the follicular stage of the cycle indicated that, depending on the dose in the organ bath, prostaglandin $E_{2}$ can either stimulate or inhibit uterine contractions and that the inhibition can be blocked by the beta-blocking agent propanolol (Rüsse, 1972). Indomethacin prevented both spontaneous and $\mathrm{PGE}_{2}$-induced contractions in the latter study. In vivo, indomethacin treatment of the late pregnant sow postpones parturition (Sherwood et al., 1979; Taverne et al., 1982) but delivery of piglets can be achieved during indomethacin treatment by infusion of high doses of prostaglandin $F_{2 \alpha}(\mathrm{Nara}, 1979)$.

\section{CATECHOLAMINES}

In myometrial tissue obtained from pigs in oestrus, dioestrus and from pregnant sows, the presence of both $\alpha$ - and $\beta$-adrenoreceptors has been demonstrated by studying the response to noradrenalin and adrenalin before and after the addition of $\alpha$ - and $\beta$-blocking agents to the organ bath (Noreisch, 1973). This in vitro study explained the results obtained in vivo by Zerobin (1968) and Bower (1974), who showed that during dioestrus, pro-oestrus, oestrus and pregnancy a biphasic response (a stimulation followed by an inhibition of several minutes) was recorded after the application of $100 \mu \mathrm{g}$ adrenalin; the stimulatory effect results from $\alpha$ receptor stimulation and the inhibitory effect from $\beta$-receptor stimulation. Also Ngiam (1974) demonstrated in vivo in the post partum sow that inhibition of uterine contractions by adrenalin could be blocked by the $\beta$-blocking agent propanolol. The physiological implications of these experiments have been illustrated both during oestrus by Bower (1974) and 
during parturition by Naaktgeboren (1979) when inhibition of uterine contractions was recorded for a varying period of time after disturbances to the environment of the sows. The authors suggested that endogenous adrenalin was responsible for this inhibition.

Recently the highly selective $\beta_{2}$-receptor sympathicomimetic compound NAB 365 (Planipart ${ }^{\circledR}$, Boehringer Ingelheim, West Germany) was found to postpone or interrupt the delivery process in sows for several hours if intravenous administration occurred either when gilts demonstrated preparturient milk production or after delivery of 1-3 piglets (Zerobin and

194

1 day

post partum

1 piglet
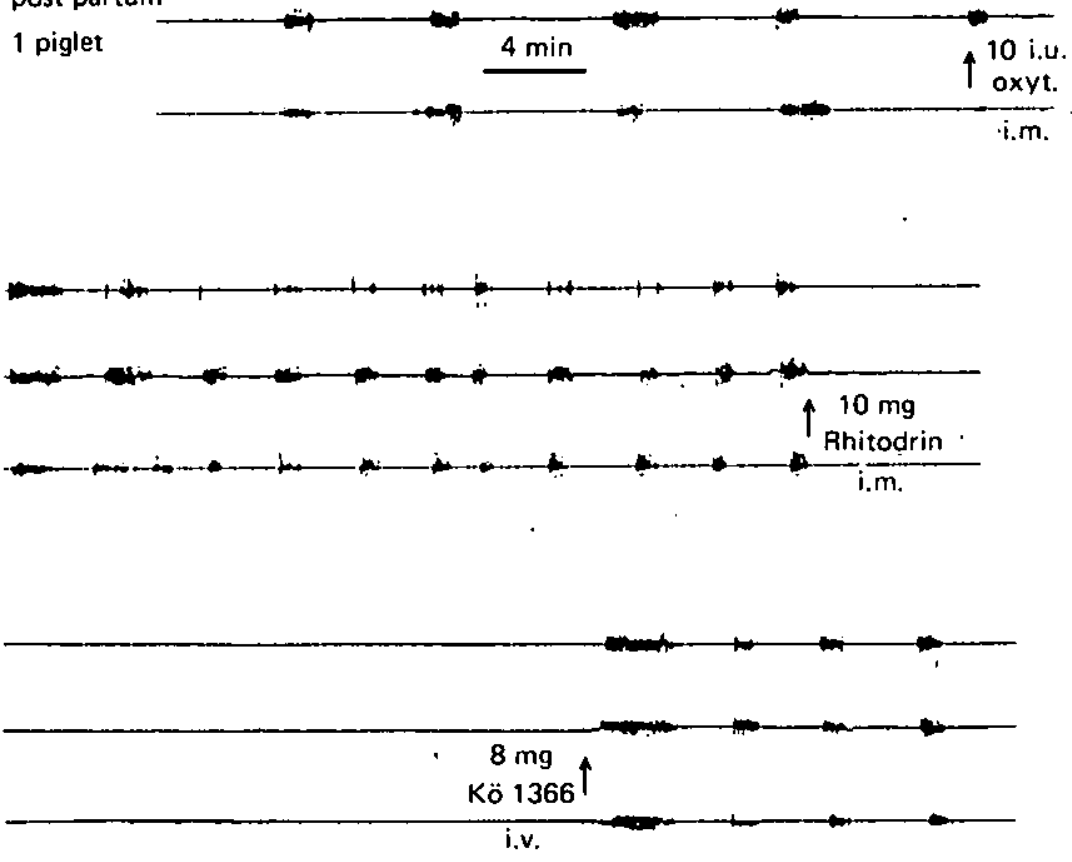

Figure 20.7 Electromyograph (in four continuous sections) recorded from three different sites of a uterine horn in a (Landrace) sow on the first day after parturition (one piglet was left with the sow). After stimulation with oxytocin (Oxytocin-S, Intervet, Boxmeer, The Netherlands), myometrial electrical activity was completely abolished by the betamimetic compound rhitodrin (Prepar, Philips Duphar, Weesp, The Netherlands) but restoration immediately occurred after the intravenous injection of the beta-blocking agent Kö 1366 (Boehringer Ingetheim, West Germany) 
Kündig, 1980). No deleterious effects on mother or on offspring were observed. The tocolytic effect of the drug was demonstrated both by recordings of EMG activity and intrauterine pressure changes. The myometrium remained responsive to oxytocin during the tocolysis but surprisingly the betalytic compound Kö 1366 (Boehringer Ingelheim, West Germany; Müller-Tyl, Reinhold and Hernuss, 1974) did not antagonize the effects of Planipart (Zerobin and Kündig, 1980). This is in contrast with our own observations in the post partum sow (Figure 20.7) in which the $\beta$-blocking drug Kö 1366 (charge 51218) immediately restored uterine activity that had been abolished previously by the administration of the betamimetic agent rhitodrin (Prepar ${ }^{\circledR}$, Philips Duphar, Weesp, The Netherlands), an agent frequently used in human obstetrics.

\section{References}

ASHDOWN, R.R. and MARRABLE, A.E. (1970). The development of the embryonic membranes in the pig: observations on the afterbirths. Res. vet. Sci. 11, 227-231

BEVIER, G.W. and DZIUK, P.J. (1976). The effect of the number of fetuses and their location in the uterus on the incidence of stillbirth. Proc. Int. Pig Vet. Soc., p.D21

BOSC, M.J., LOCATELLI, A., NICOLLE, A. and DU MESNIL DU BUISSON, F. (1976). Effect of inversion of one or both uterine horns on farrowing in sow. Annls Biol. anim. Biochim. Biophys. 16, 645-648

BOWER, R.E. (1974). Factors affecting myometrial activity in the pig. $\mathrm{PhD}$ Thesis. University of Minnesota

CARTER, A.M., NAAKTGEBOREN, C. and VAN ZON- VAN WAGTENDONK, A.M. (1971). Parturition in the rabbit: spontaneous uterine activity during late pregnancy, parturition and the post partum period and its relation to normal behaviour. Eur. J. Obstet. Gynec. 2, 37-68

CHARD, T. and FORSLING, M.L. (1976). Hormones in Blood, (H.N. Antoniades, Ed.). pp. 485-516. Harvard University Press.

COLENBRANDER, B. (1974). The influence of oestradiol and progesterone on the catecholamine content of the genital tract of the sow. Acta morph neerl. scand. 12, 243-256

CORT, N., EINARSSON, S. and VIRING, S. (1979). Actions of oxytocin and a long acting carba oxytocin analog on the porcine myometrium in vitro and in vivo. Am. J. vet. Res. 40, 430-432

CSAPO, A.J., ESKOLA, J. and RUTTNER, Z. (1980). The biological meaning of progesterone levels. Prostaglandins 19, 203-211

DIAS E SILVA, U. (1979). In-vitro Untersuchungen zur Beeinfluszbarkeit isolierter Uterusstreifen von Sauen mit unterschiedlicher Geburtsdauer. Inaugural Dissertation Tierärztliche Hochschule, Hannover.

DIELEMAN and SCHOENMAKERS (1979). Radioimmunoassays to determine the presence of progesterone and estrone in the starfish Asterias rubens. Gen. Comp. Endocr. 39, 534-542

DÖCKE, F. and WORCH, H. (1963). Untersuchungen über die Uterusmotilität und die Paarungsreaktionen der Sau. Zuchthygiene 7, 169-178

DZIUK, P.J. (1979). Control and mechanics of parturition in the pig. Anim. Reprod. Sci. 2, 335-342 
DZIUK, P.J. and HARMON, B.G. (1969). Succession of fetuses at parturition in the pig. Am. J. vet. Res. 30, 419-421

ELLENDORFF, F., TAVERNE, M., ELSAESSER, F., FORSLING, M., PARVIZI, N., NAAKTGEBOREN, C. and SMIDT, D. (1979a). Endocrinology of parturition in the pig. Anim. Reprod. Sci. 2, 323-334

ELLENDORFF, F., FORSLING, M., PARVIZI, N., WILLIAMS, H., TAVERNE, $M$. and SMIDT, D. (1979b). Plasma oxytocin and vasopressin concentrations in response to prostaglandin injection into the pig. J. Reprod. Fert. 56, 573-577

ELLICOTT, A.R. and DZIUK, P.J. (1973). Minimum daily dose of progesterone and plasma concentrations for maintenance of pregnancy in ovariectomized gilts. Biol. Reprod. 9, 300-304

FIRST, N.L. and BOSC, M.J. (1979). Proposed mechanisms controlling parturition and the induction of parturition in swine. J. Anim. Sci. 48, $1407-1421$

FLINT, A.P.F., RICKETTS, A.P. and CRAIG, V.A. (1979). The control of placental steroid synthesis at parturition in domestic animals. Anim. Reprod. Sci. 2, 239-251

FORSLING, M.L., MACDONALD, A.A. and ELLENDORFF, F. (1979). The neurohypophysial hormones. Anim. Reprod. Sci. 2, 43-56

FORSLING, M.L., TAVERNE, M.A.M., PARVIZI, N., ElSAESSER, F., SMIDT, D. and ELLENDORFF, F. (1979). Plasma oxytocin and steroid concentrations during late pregnancy, parturition and lactation in the miniature pig. $J$. Endocr. 82, 61-69

JÖCHLE, W., OROZCO, L., ZEROBIN, K., ESPARZA, H. and HIDALGO, M.A. (1974). Effects of a progestin on parturition and the post-partum period in pigs. Theriogenology 2, 11-20

KEYE, J.D. (1923). Periodic variations in spontaneous contractions of uterine muscle, in relation to the oestrous cycle and early pregnancy. Johns Hopkins Hosp. Bull. 384, 60-63

KING, J.L. (1927). Observations on the activity and working power of the uterine muscle of the non-pregnant sow. Am. J. Physiol. 81, 725-737

LEIBRECHT, R. (1953). Uber die Struktur der Ringmuskelschicht am Uterus von Rind und Schwein and ihre funktionelle Bedeutung. Inaugural Dissertation Tierärztliche Fakultät, Universität München.

LUDWIG, K.S. (1952). Die Architektur der Muskelwand im Rattenuterus. Acta Anat. 15, 23-41

LYE, S.J. (1980). The hormonal control of myometrial activity in the sheep and rat. PhD Thesis. University of Bristol

MARTIN, K.A. (1980). Effects of partial fetectomy in the sow. Thesis. University of Guelph

MINAR, M. and SCHILLING, E. (1970). Die Beeinflussung des Geburtstermins beim Schwein durch gestagene Hormone. Dt. tierärztl. Wschr. 77, 428-431

MOELJONO, M.P.E., THATCHER, W.W., BAZER, E.W., FRANK, M., OWENS, L.J. and WILCOX, C.J. (1977). A study of prostaglandin $F_{2 \alpha}$ as the luteolysin in swine: II. Characterization and comparison of prostaglandin $F_{2 \alpha}$, estrogen and progestin concentrations in utero-ovarian vein plasma of non-pregnant and pregnant gilts. Prostaglandins 14, 543-555

MÜLLER-TYL, E., REINHOLD, E. and HERNUSS, P. (1974). Gleichzeitige 
Anwendung einer beta-mimetischen und beta-rezeptorenblockierenden Substanz bei der Wehenhemmung. Z. Geburtsh. Perinat. 178, 128-134 NAAKTGEBOREN, C. (1979). Behavioural aspects of parturition. Anim. Reprod. Sci. 2, 155-166

NAAKTGEBOREN, C. and CARTER, A.M. (1971). Oryctolagus cuniculus (Leporidae): Uterusaktivität wahrend der Geburt. In Encyclopaedia Cinematographica, (G. Wolf, Ed.), Film E 1649

NAAKTGEBOREN, C., POOL, C., VAN DER WEYDEN, G.C., TAVERNE, M.A.M., SCHOOF, A.G. and KROON, C.H. (1975). Elektrophysiologische Untersuchungen über die Uteruskontraktionen des Schafes während der Trächtigkeit und der Geburt. Z. Tierzucht. Zücht Biol. 92, 220-243

NAGLER, M. (1956). Untersuchungen uber Struktur und Funktion des Schweine-uterus. Inaugural Dissertation Tierärztliche Fakultät, Universität München

NARA, B.S. (1979). Mechanisms controlling prepartum luteolysis in swine. PhD Thesis. University of Wisconsin, Madison, USA

NGIAM, T.T. (1974). A study of the involuting porcine uterus with special reference to its histology, histochemistry and its response to bacterial infection. PhD Thesis. Royal Veterinary College, University of London NGIAM, T.T. (1977). A study of the motility of the uterus of the sow during the peri-parturient period. Singapore vet. J. 1, 13-27

NOREISCH, w. (1973). Adrenozeptoren im Myometrium des Schweines. Inaugural Dissertation Tierärztliche Fakultät, Universität München PERRY, J.S. (1954). Parturition in the pig. Vet. Rec. 66, 706-708

PRUD'HOMME, M.J. (1980). Effect of an inhibition of prostaglandin synthesis on uterine motility in the ovariectomized ewe during induced oestrus. A preliminary report. Theriogenology 14, 349-359

PRUD'HOMME, M.J. and BOSC, M.J. (1977). Motricité utérine de la brebis, avant, pendant et après la parturition spontanée ou après traitement par la dexamethasone. Annls Biol. anim. Biochim. Biophys. 16, 645-648

RANDALL, G.C.B. (1972). Observations on parturition in the sow. II. Factors influencing stillbirth and perinatal mortality. Vet. Rec. 90, 183-186

RANDALL, G.C.B. (1979). Studies on the effect of acute asphyxia on the fetal pig in utero. Biol. Neonate 36, 63-69

RÜSSE, M.W. (1972). Die Bedeutung von Prostaglandin $E_{2}$ in der Steuerung der Kontraktionen des Uterus. 1. Mitteilung: In-vitro Unter-suchungen am Myometrium des Schweines. Zuchthygiene 7, 162-169

SCHEERBOOM, J.E.M. and TAVERNE, M.A.M. (1981). Combined electromyography and real-time ultrasound scanning of the pregnant uterus of the ewe. Eur. J. Obstet. Gynec. and reprod. Biol., in press

SHERWOOD, O.D., NARA, B.S., CRNEKOVIC, V.E. and FIRST, N.L. (1979). Relaxin concentrations in pig plasma after the administration of indomethacin and prostaglandin $\mathrm{F}_{2 \alpha}$ during late pregnancy. Endocrinology 104, 1716-1721

SHILLE, V.M., KARLBOM, I., EINARSSON, S., LARSSON, K., KINDAHL, H. and EDQVIST, L.E. (1979). Concentrations of progesterone and 15-keto13,14-dihydro-prostaglandin $F_{2 \alpha}$ in peripheral plasma during estrus cycle and early pregnancy in gilts. Zentbl. VetMed. A26, 169-181 
SILVER, M., BARNES, R.J., COMLINE, R.S., FOWDEN, A.L., CLOVER, L. and MITCHELL, M.D. (1979). Prostaglandins in the foetal pig and prepartum endocrine changes in mother and foetus. Anim. Reprod. Sci. 2, 305-322

SOLOFF, M.S. (1975). Uterine receptor for oxytocin: effects of estrogen. Biochem. Biophys. Res. Commun. 65, 205-212

SOLOFF, M.S. and SWARTZ, T.L. (1974). Characterization of a proposed oxytocin receptor in the uterus of the rat and sow. J. biol. Chem. 249, 1376-1381

SPRECHER, D.J., LEMAN, A.D., DZIUK, P.J., CROPPER, M. and DEDECKER, M. (1974). Causes and control of swine stillbirths. J. Am. vet. med. Ass. 165, 698-701

TAVERNE, M. (1979). Physiological aspects of parturition in the pig. PhD Thesis. University of Utrecht

TAVERNE, M.A.M., NAAKTGEBOREN, C. and VAN DER WEYDEN, G.C. (1979). Myometrial activity and expulsion of fetuses. Anim. Reprod. Sci. 2, 117-131

TAVERNE, M.A.M., VAN DER WEYDEN, G.C. and FONTIJNE, P. (1979). Preliminary observations on myometrial electrical activity before, during and after parturition in the cow. In Calving Problems and Early Viability of the Calf, (B. Hoffman, I.L. Mason and J. Schmidt, Eds.). Current Topics in Veterinary Medicine and Animal Science 4, 297-311

TAVERNE, M., BEVERS, M., BRADSHAW, J., DIELEMAN, S.J., WILLEMSE, A.H. and PORTER, D.G. (1982). Plasma concentrations of prolactin, progesterone, relaxin and oestradiol- $17 \beta$ in sows treated with either progesterone, bromoergocryptine or indomethacin during late pregnancy. J. Reprod. Fert. 65, in press

TAVERNE, M.A.M., VAN DER WEYDEN, G.C., FONTIJNE, P., ELLENDORFF, F., NAAKTGEBOREN, C. and SMIDT, D. (1977). Uterine position and presentation of mini-pig fetuses and their order and presentation at birth. $A m . J$. vet. Res. 38, 1761-1764

TAVERNE, M.A.M., NAAKTGEBOREN, C., ELSAESSER, F., FORSLING, M.L., VAN DER WEYDEN, G.C., ELLENDORFF, F. and SMIDT, D. (1979). Myometrial electrical activity and plasma concentrations of progesterone, oestrogens and oxytocin during late pregnancy and parturition in the miniature pig. Biol. Reprod. 21, 1125-1134

WELK, F. and FIRST, N.L. (1979). Effect of oxytocin on the synchrony of parturition induced by $\mathrm{PGF}_{2 \alpha}$ (ICI 80996). J. Anim. Sci. 49 (Suppl. 1), 347-348

VAN DER WEYDEN, G.C., TAVERNE, M.A.M., DIELEMAN, S.J. and FONTIJNE, P. (1981a). Myometrial electrical activity throughout the entire course of pregnancy in the ewe. Eur. J. Obstet. Gynec. reprod. Biol. 11, 347-354 VAN DER WEYDEN, G.C., TAVERNE, M.A.M., OKKENS, A.C. and FONTIJNE, P. (1981b). The intrauterine position of canine foetuses and their sequence of expulsion at birth. J. Small Anim. Pract., 22, 503-510

WRATHALL, A.E. (1980). Pathology of the ovary and ovarian disorders in the sow. Proc. 9th Int. Congr. Anim. Reprod. A.I., Madrid, 1980, Vol. I, pp. 223-244

ZEROBIN, K. (1968). Untersuchungen über die Uterusmotorik des Schweines. Zentbl. VetMed. A15, 740-798 
436. Myometrial activity during pregnancy and parturition in the pig

ZEROBIN, K. and KÜNDIG, H. (1980). The control of myometrial functions during parturition with a $\beta_{2}$-mimetic compound, Planipart ${ }^{\circledR}$. Theriogenology 14, 21-35

ZEROBIN, K. and SPÖRRI, H. (1972). Motility of the bovine and porcine uterus and Fallopian tube. Adv. vet. Sci. comp. Med. 16, 303-354 